\title{
Inheritance of Fresh Seed Dormancy in Peanut
}

\author{
H. D. Upadhyaya* and S. N. Nigam
}

\begin{abstract}
Incorporation of seed dormancy of limited duration in Spanish peanut (Arachis hypogaea L.) genotypes is required to avoid loss in pod yield and seed quality because of in situ germination in unpredictable rainfall environments. Knowledge of inheritance of fresh seed dormancy is important to peanut breeders for developing fresh seed dormant early-maturing Spanish cultivars. This study was conducted to determine the inheritance of fresh seed dormancy using three Spanish peanut genotypes. Two dormant (ICGV 86158 and ICGV 87378) and one non-dormant (JL 24) genotypes were crossed in all possible combinations, including reciprocals. The fresh seeds from mature pods from parents, $F_{1}, F_{2}, F_{3}$, and backcross populations were evaluated for their dormancy by germination tests in the laboratory at $35 \pm 2^{\circ} \mathrm{C}$ in the dark. Results showed that the fresh seed dormancy in these genotypes is controlled by a dominant allele of a single gene. The two dormant parents, ICGV 86158 and ICGV 87378, possess the same allele for fresh seed dormancy.
\end{abstract}

$\mathrm{P}$ EANUT GENOTYPES belonging to Spanish (subsp. fastigiata var. vulgaris) and Valencia (subsp. fastigiata var. fastigiata) types have short life cycles and non dormant seeds, while those of Virginia (subsp. hypogaea var. hypogaea) type have long life cycles and dormant seeds. Spanish types are predominantly grown in the semi arid regions of Asia and Africa where the growing season is short or peanut is grown in multiple cropping systems. Rains immediately prior to harvest can cause the seeds of Spanish and Valencia genotypes to sprout in the ground. In the semi arid tropics, which account for about $60 \%$ of global peanut production area, such situations are frequent and losses in yield and quality can be substantial. To avoid these losses it is essential to have fresh seed dormancy of 2 to 3 wk duration in Spanish cultivars. Breeding such cultivars is an important objective in most peanut improvement programs.

The physiological basis for dormancy in peanut has been investigated and shown to result from the hormonal balance between abscisic acid, which acts as a germination inhibitor, and ethylene, which acts as a germination activator and is produced by the embryo through the action of cytokinin during seed imbibition (Ketring and Morgan, 1971, 1972). Depending on their genetic constitution, different seed parts-seed coat, cotyledons, and embryo-have been reported to have a role in imparting dormancy (Nautiyal et al., 1994). However, seed dormancy is an inherent property of peanut seed and it does not depend on an impervious or protective seed coat (Hammons, 1973).

There have been a few studies on the inheritance of seed dormancy in peanut. These studies have drawn

Groundnut Improvement Project, ICRISAT Center, Patancheru, 502 324, Andhra Pradesh, India. ICRISAT J.A. no. 2231. Received 14 Jan. 1998. *Corresponding author (H.UPADHYAYA@CGNET.COM).

Published in Crop Sci. 39:98-101 (1999). contradictory conclusions. Lin and Lin (1971) reported monogenic control, whereas Hull (1.937) and John et al. (1948) reported polygenic control. Lin and Lin (1971) used the seeds 2 wk after harvest from reciprocal crosses between a Spanish cultivar and three Virginia cultivars of different dormancy duration. Hull (1937) used the seeds $10 \mathrm{~d}$ after harvest in eight crosses involving Spanish or Valencia and the Virginia type parents. Nautiyal et al. (1994) indicated that the character may be quantitatively inherited. Lin and Lin (1971) reported complete dominance of dormant over non-dormant seed, whereas Stokes and Hull (1930) and Ramchandran et al. (1967), using Spanish $\times$ Virginia crosses, observed partial dominance. Khalfaoui (1991) used fresh seeds of a cross between two Spanish types and concluded that dormancy is a quantitatively inherited trait and that additive, dominance, and digenic epistatic effects were involved in its genetic control.

The objective of this investigation was to determine the inheritance of fresh seed dormancy in crosses involving three Spanish genotypes, JL 24, ICGV 86158, and ICGV 87378.

\section{MATERIALS AND METHODS}

Three Spanish peanut genotypes-JL 24 (released name 'Phule Pragati'), ICGV 86158, and ICGV 87378-were selected for this study which was conducted at the ICRISAT Center, Patancheru, India. JL 24, a short-duration Indian cultivar, is non-dormant (Patil et al., 1980) and ICGV 86158 (PI 594971) and ICGV 87378 (PI 594972) are dormant germplasm developed at ICRISAT (Upadhyaya et al., 1997). ICGV 86158 is an elite germplasm derived from a cross involving a Spanish line ICGS 30 and an $F_{6}$ breeding line from a cross between the Virginia line TMV 10, and the early-maturing Spanish line, Chico (Bailey and Hammons, 1975). ICGV 87378 is a bulk selection from Kanto No. 40, a Spanish germplasm line from Japan, also known as ICG 7261 or EC 123074.

JL 24, ICGV 86158, and ICGV 87378 were crossed in all possible combinations including reciprocals in the glasshouse. Each of the resultant six $F_{1}$ hybrids was crossed to both parents to generate 12 backcrosses and selfed to produce six $F_{2}$ populations in the 1992-1993 postrainy season. The parents were crossed once again to produce fresh $F_{1}$ seeds for evaluating with the parents, backcrosses, and $F_{2}$ populations. The filial generations in this study were designated on the basis of the embryonic genotype, thus the $F_{1}$ seeds were those obtained immediately after crossing of female and male parents, and the $F_{2}$ seeds were those obtained by selfing the $F_{1}$ plants.

The dormancy of parents, $F_{1}, F_{2}$, and backcross $F_{1}$ generations was assessed in the laboratory by incubating noncured seeds from freshly harvested mature pods from the 1992-1993 postrainy season. The maturity of pods was ascertained by the development of black coloration inside the shell (Miller and Burns, 1971). Care was taken not to damage the testa while removing seed from the pods. Seeds were treated with Captan, $n$-[(trichloromethyl) thio]-4-cyclohexene-1,2-dicarboxymide, at $2 \mathrm{~g} \mathrm{~kg}^{-1}$ seed, placed on filter paper in a petri dish which was kept moist with distilled water during the 
Table 1. The chi-square values and probabilities of goodness of fit for a ratio of 3 dormant:1 non-dormant in the $F_{2}$, and $F_{3}$ generations of crosses of ICGV 86158 and ICGV 87378 with JL 24 in the 1993 rainy (R) and 1992-1993 and 1994-1995 postrainy (PR) seasons.

\begin{tabular}{|c|c|c|c|c|c|c|c|}
\hline \multirow[b]{2}{*}{ Cross } & \multirow[b]{2}{*}{ Season } & \multirow[b]{2}{*}{ Generation } & \multicolumn{3}{|c|}{ Number of seeds } & \multirow[b]{2}{*}{$x^{2}$} & \multirow[b]{2}{*}{$\boldsymbol{P}$} \\
\hline & & & Total & Dormant & Nondormant & & \\
\hline $\begin{array}{l}\text { Pooled over segregating progenies } \\
\text { Total } \\
\text { Heterogeneity }\end{array}$ & $\begin{array}{l}1992-1993 \text { PR } \\
1993 \text { R } \\
1994-1995 \text { PR } \\
1994-1995 \text { PR }\end{array}$ & $\begin{array}{l}\mathbf{F}_{2} \\
\mathbf{F}_{2} \\
\mathbf{F}_{2} \\
\mathbf{F}_{3}\end{array}$ & $\begin{array}{r}85 \\
262 \\
408 \\
898 \\
1653\end{array}$ & $\begin{array}{r}70 \\
195 \\
305 \\
668 \\
1238\end{array}$ & $\begin{array}{r}15 \\
67 \\
103 \\
230 \\
415\end{array}$ & $\begin{array}{l}2.451 \\
0.046 \\
0.013 \\
\mathbf{0 . 1 8 0} \\
\mathbf{0 . 0 1 0} \\
\mathbf{2 . 6 8 0}\end{array}$ & $\begin{array}{l}\mathbf{0 . 1 1 7} \\
0.830 \\
0.909 \\
0.671 \\
\mathbf{0 . 9 2 3} \\
\mathbf{0 . 4 4 4}\end{array}$ \\
\hline $\begin{array}{l}\text { Pooled over segregating progenies } \\
\text { Total } \\
\text { Heterogeneity }\end{array}$ & $\begin{array}{l}\text { 1992-1993 PR } \\
1993 \text { R } \\
\text { 1994-1995 PR } \\
\text { 1994-1995 PR }\end{array}$ & $\begin{array}{l}\mathbf{F}_{2} \\
\mathbf{F}_{2} \\
\mathbf{F}_{2} \\
\mathbf{F}_{3}\end{array}$ & $\begin{array}{r}75 \\
225 \\
466 \\
783 \\
1549\end{array}$ & $\begin{array}{r}53 \\
\mathbf{1 8 0} \\
\mathbf{3 3 9} \\
\mathbf{5 6 7} \\
\mathbf{1 1 3 9}\end{array}$ & $\begin{array}{r}22 \\
45 \\
127 \\
216 \\
410\end{array}$ & $\begin{array}{l}0.751 \\
3.000 \\
1.262 \\
2.793 \\
1.782 \\
6.024\end{array}$ & $\begin{array}{l}0.386 \\
0.083 \\
0.261 \\
0.095 \\
0.182 \\
0.110\end{array}$ \\
\hline $\begin{array}{l}\text { Pooled over segregating progenies } \\
\text { Total } \\
\text { Heterogeneity }\end{array}$ & $\begin{array}{l}\text { 1992-1993 PR } \\
1993 \text { R } \\
\text { 1995-1996 PR } \\
\text { 1995-1996 PR }\end{array}$ & $\begin{array}{l}\mathbf{F}_{2} \\
\mathbf{F}_{2} \\
\mathbf{F}_{2} \\
\mathbf{F}_{3}\end{array}$ & $\begin{array}{r}80 \\
78 \\
311 \\
415 \\
884\end{array}$ & $\begin{array}{r}64 \\
63 \\
226 \\
298 \\
651\end{array}$ & $\begin{array}{r}16 \\
15 \\
85 \\
117 \\
233\end{array}$ & $\begin{array}{l}1.067 \\
1.385 \\
0.901 \\
2.256 \\
0.869 \\
4.740\end{array}$ & $\begin{array}{l}0.302 \\
0.239 \\
0.343 \\
0.133 \\
0.351 \\
0.192\end{array}$ \\
\hline $\begin{array}{l}\text { Pooled over segregating progenies } \\
\text { Total } \\
\text { Heterogeneity }\end{array}$ & $\begin{array}{l}\text { 1992-1993 PR } \\
1993 \text { R } \\
1995-1996 \text { PR } \\
\text { 1995-1996 PR }\end{array}$ & $\begin{array}{l}\mathbf{F}_{2} \\
\mathbf{F}_{2} \\
\mathbf{F}_{2} \\
\mathbf{F}_{3}\end{array}$ & $\begin{array}{r}51 \\
131 \\
282 \\
616 \\
1080\end{array}$ & $\begin{array}{r}31 \\
98 \\
201 \\
\mathbf{4 4 5} \\
\mathbf{7 7 5}\end{array}$ & $\begin{array}{r}\mathbf{2 0} \\
33 \\
81 \\
\mathbf{1 7 1} \\
\mathbf{3 0 5}\end{array}$ & $\begin{array}{l}5.497 \\
0.003 \\
2.085 \\
2.502 \\
6.049 \\
4.038 \\
\end{array}$ & $\begin{array}{l}0.019 \\
0.956 \\
0.149 \\
0.114 \\
0.014 \\
0.257 \\
\end{array}$ \\
\hline
\end{tabular}

course of the study, and incubated at $35 \pm 2^{\circ} \mathrm{C}$ in the dark in an incubator. The number of germinating seeds was recorded daily for $35 \mathrm{~d}$ after incubation. On the 36 th day, to test the viability of the seeds which did not germinate, $0.05 \%$ ethrel (2-chloroethyl-phosponic acid) solution was sprayed on them to stimulate germination. To confirm the behavior and separate selfs from crossed seeds, the germinating $F_{1}$ seeds of all crosses were transplanted to $10-\mathrm{cm}$ plastic pots in the glasshouse. The parents were also grown to obtain fresh seeds for evaluation with the seeds from the $F_{2}$ generation. The $15 \mathrm{~d}$ old seedlings were transplanted to the field, alfisols-Patancheru Soil Series (Udic Rhodustolf) and grown on $60-\mathrm{cm}$ ridges. Parents and $F_{1}$ plants were harvested individually and seeds of each plant tested for fresh seed dormancy in the 1993 rainy season.

The crosses involving ICGV 86158 and JL 24 were studied in detail in the 1994-1995 postrainy season and those involving ICGV 87378 and JL 24 in the 1995-1996 postrainy season by incubating fresh seeds of each plant progenies separately in a test that included the parents, $\mathrm{F}_{1}, \mathrm{~F}_{2}, \mathrm{~F}_{3}$, and backcross generations (ICGV $86158 \times\left(\right.$ ICGV $\left.86158 \times \mathrm{JL} 24 \mathrm{~F}_{1}\right)$, ICGV $86158 \times\left(\mathrm{JL} 24 \times \mathrm{ICGV} 86158 \mathrm{~F}_{1}\right), \mathrm{JL} 24 \times(\mathrm{ICGV} 86158 \times$ JL $\left.24 \mathrm{~F}_{1}\right)$, JL $24 \times\left(\mathrm{JL} 24 \times \mathrm{ICGV} 86158 \mathrm{~F}_{1}\right), \mathrm{ICGV} 87378 \times$ $\left(\right.$ ICGV $87378 \times$ JL $\left.24 \mathrm{~F}_{1}\right)$, ICGV $87378 \times(\mathrm{JL} 24 \times$ ICGV $\left.87378 \mathrm{~F}_{1}\right), \mathrm{JL} 24 \times\left(\mathrm{ICGV} 87378 \times \mathrm{JL} 24 \mathrm{~F}_{1}\right), \mathrm{JL} 24 \times(\mathrm{JL}$ $24 \times$ ICGV $87378 \mathrm{~F}_{1}$ ). Plant progenies which had cumulative germination similar to the dormant parents after 2 wk of incubation were classified as dormant. Progenies with a germination pattern similar to the non-dormant parent were classified as non-segregating, non-dormant. The remaining progenies in the $F_{3}$ and backcross $F_{2}$ generations were classified as segregating. Chi-square tests were applied to test the goodness of fit of the observed to the expected ratios in all populations.

\section{RESULTS AND DISCUSSION}

In the $1992-1993$ postrainy season, all 100 seeds of JL 24 and only three of 100 seeds each of ICGV 86158 and ICGV 87378 had germinated after 2 wk of incubation. The progenies of the six seeds which germinated were found to be dormant. This confirmed the non-dormant nature of JL 24 and dormant nature of ICGV 86158 and ICGV 87378.

In the $F_{1}$ generation of dormant $\times$ non-dormant crosses, the percentage of seeds which germinated was similar to the dormant parent $(<10 \%)$. The dormancy of the $F_{1}$ seeds indicated that fresh seed dormancy in

Table 2. The chi-square values and probabilities of goodness of fit for expected ratio of 1 dormant:1 non-dormant seeds in the backcross $F_{1}$ generations of crosses of ICGV 86158 and ICGV 87378 with JL 24.

\begin{tabular}{|c|c|c|c|c|c|}
\hline Cross & Total seeds & Dormant & Non-dormant & $x^{2}$ & $\boldsymbol{P}$ \\
\hline 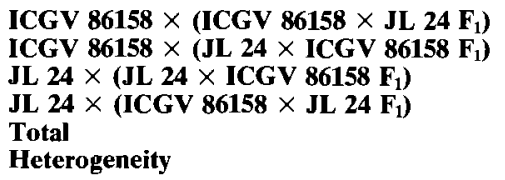 & $\begin{array}{l}36 \\
43 \\
30 \\
41 \\
71\end{array}$ & $\begin{array}{l}36 \\
43 \\
16 \\
26 \\
42\end{array}$ & $\begin{array}{r}0 \\
0 \\
14 \\
15 \\
29\end{array}$ & $\begin{array}{l}- \\
\overline{-} \\
\mathbf{0 . 1 3 3} \\
\mathbf{2 . 9 5 1} \\
\mathbf{2 . 3 8 0} \\
\mathbf{0 . 7 0 4}\end{array}$ & $\begin{array}{l}- \\
\overline{-} \\
0.715 \\
0.086 \\
\mathbf{0 . 1 2 3} \\
\mathbf{0 . 4 0 1}\end{array}$ \\
\hline $\begin{array}{l}\text { ICGV } 87378 \times\left(\text { ICGV } 87378 \times J_{L} 24 F_{1}\right) \\
\text { ICGV } 87378 \times\left(J L 24 \times \text { ICGV } 87378 F_{1}\right) \\
\text { JL } 24 \times\left(J L 24 \times \text { ICGV } 87378 F_{1}\right) \\
\text { JL } 24 \times\left(I C G V 87378 \times J_{L} 24 F_{1}\right) \\
\text { Total } \\
\text { Heterogeneity }\end{array}$ & $\begin{array}{r}48 \\
40 \\
60 \\
48 \\
108\end{array}$ & $\begin{array}{l}\mathbf{4 8} \\
\mathbf{3 7} \\
\mathbf{2 8} \\
\mathbf{2 5} \\
\mathbf{5 3}\end{array}$ & $\begin{array}{r}0 \\
3 \\
32 \\
23 \\
55\end{array}$ & $\begin{array}{c}- \\
\overline{-} \\
\mathbf{0 . 2 6 7} \\
\mathbf{0 . 0 8 3} \\
\mathbf{0 . 0 3 7} \\
\mathbf{0 . 3 1 3}\end{array}$ & $\begin{array}{l}- \\
\overline{0} \\
0.605 \\
0.773 \\
0.848 \\
0.576\end{array}$ \\
\hline
\end{tabular}


Table 3. The chi-square values and probabilities of goodness of fit for a ratio of 1 non-segregating dormant:2 segregating:1 non-segregating non-dormant progenies in the $F_{3}$ generations of crosses of ICGV 86158 and ICGV 87378 with JL 24.

\begin{tabular}{|c|c|c|c|c|c|}
\hline Cross & $\begin{array}{c}\text { Non-segregating } \\
\text { dormant }\end{array}$ & Segregating & $\begin{array}{l}\text { Non-segregating } \\
\text { non-dormant }\end{array}$ & $x^{2}$ & $\boldsymbol{P}$ \\
\hline $\begin{array}{l}\text { ICGV } 86158 \times \text { JL } 24 \\
\text { JL } 24 \times \text { ICGV } 86158 \\
\text { Total } \\
\text { Heterogeneity }\end{array}$ & $\begin{array}{l}15 \\
17 \\
32\end{array}$ & $\begin{array}{l}40 \\
32 \\
72\end{array}$ & $\begin{array}{l}13 \\
11 \\
24\end{array}$ & $\begin{array}{l}2.235 \\
1.467 \\
3.000 \\
\mathbf{0 . 7 0 2}\end{array}$ & $\begin{array}{l}0.327 \\
0.486 \\
0.223 \\
0.704\end{array}$ \\
\hline $\begin{array}{l}\text { ICGV } 87378 \times \text { JL } 24 \\
\text { JL } 24 \times \text { ICGV } 87378 \\
\text { Total } \\
\text { Heterogeneity }\end{array}$ & $\begin{array}{l}16 \\
17 \\
33\end{array}$ & $\begin{array}{l}32 \\
33 \\
65\end{array}$ & $\begin{array}{l}21 \\
24 \\
45\end{array}$ & $\begin{array}{l}\mathbf{1 . 0 8 7} \\
\mathbf{2 . 1 8 9} \\
\mathbf{3 . 1 9 5} \\
\mathbf{0 . 0 8 1}\end{array}$ & $\begin{array}{l}0.581 \\
0.335 \\
0.202 \\
0.960\end{array}$ \\
\hline
\end{tabular}

ICGV 86158 and ICGV 87378 is dominant over nondormancy in JL 24.

In the $F_{2}$ generation, the numbers of dormant and non-dormant seeds from all crosses between dormant and non-dormant parents fit a 3:1 ratio (Table 1) suggesting that fresh seed dormancy is controlled by a dominant allele of a single gene. In the backcross generations with the ICGV 86158 and ICGV 87378 parents all seeds except for the three in the backcross with later parent were dormant. In the backcross generations with JL 24 parent the number of dormant and non-dormant seeds fit a 1:1 ratio (Table 2), supporting the conclusion of single gene inheritance.

Data from the $\mathrm{F}_{3}$ progenies fit an expected 1:2:1 ratio of dormant, non-segregating: segregating: non-dormant, non-segregating progenies (Table 3 ). The segregating $F_{3}$ progenies showed an excellent fit to a 3 dormant:1 non-dormant ratio individually as well as on a pooled basis (Table 1). This further indicated that dormancy is controlled by a dominant allele of a single gene.

Backcross progenies with the dormant parent fit to an expected 1 dormant non-segregating: 1 segregating ratio. Similarly, progenies from backcross with the nondormant parent fit to an expected 1 segregating: 1 nondormant, non-segregating ratio. The segregating progenies in these backcross $\mathrm{F}_{2}$ generations showed a good fit to a 3 dormant:1 non-dormant ratio on individual as well as pooled basis (Table 4). This confirmed the earlier conclusion that fresh seed dormancy in crosses involving
JL 24, ICGV 86158, and ICGV 87378 is controlled by a dominant allele of a single gene.

In the cross involving the two dormant parents, ICGV 86158 and ICGV 87378 , only 1 out of $50 F_{1}$ seeds in the ICGV $86158 \times$ ICGV 87378 cross and none out of $50 F_{1}$ seeds in the ICGV $87378 \times$ ICGV 86158 cross germinated after 2 wk of incubation, indicating the dormancy of the $F_{1}$ hybrid. In the $F_{2}$ generation only 1 out of 66 seeds in the ICGV $86158 \times$ ICGV 87378 cross and 1 out of 60 seeds in the ICGV $87378 \times$ ICGV 86158 cross germinated in the 1992-1993 postrainy season, indicating no segregation for dormancy. In another test with the $F_{2}$ generation in the 1993 rainy season, only 3 seeds out of 226 in the ICGV $86158 \times$ ICGV 87378 cross and only 1 seed out of 454 in the ICGV $87378 \times$ ICGV 86158 cross germinated. In the backcross generations, the number of seeds germinated was 2 out of 45 in ICGV $86158 \times\left(\mathrm{ICGV} 86158 \times \mathrm{ICGV} 87378 \mathrm{~F}_{1}\right), 2$ out of 57 in ICGV $86158 \times($ ICGV $87378 \times$ ICGV $\left.86158 \mathrm{~F}_{1}\right)$, none out of 42 in ICGV $87378 \times(\mathrm{ICGV}$ $87378 \times$ ICGV $86158 \mathrm{~F}_{1}$ ), and 1 out of 36 in ICGV $87378 \times\left(\right.$ ICGV $86158 \times$ ICGV $\left.87378 \mathrm{~F}_{1}\right)$. The possible reason for these putative dormant seeds to germinate could be their relative over maturity vis-a-vis other seeds included in the study. All these germinating seeds were progeny tested for germination and were subsequently found to be dormant. This would indicate that the dominant allele of the gene for dormancy in the two dormant parents, ICGV 86158 and ICGV 87378 is at the same

Table 4. The chi-square values and probabilities of goodness of fit for a ratio of 3 dormant:1 non-dormant in the segregating progenies in hackcross $F_{2}$ generations of crosses involving ICGV 86158 and ICGV 87378 with JL 24 in the 1994-1995 and $1995-1996$ postrainy (PR) seasons.

\begin{tabular}{|c|c|c|c|c|c|c|}
\hline \multirow[b]{2}{*}{ Cross } & \multirow[b]{2}{*}{ Season } & \multicolumn{3}{|c|}{ Number of seeds } & \multirow[b]{2}{*}{$x^{2}$} & \multirow[b]{2}{*}{$P$} \\
\hline & & Total & Dormant & Non-dormant & & \\
\hline $\begin{array}{l}\text { ICGV } 86158 \times\left(\text { ICGV } 86158 \times \text { JL } 24 F_{1}\right) \\
\text { ICGV } 86158 \times\left(\text { JL } 24 \times \text { ICGV } 86158 F_{1}\right) \\
\text { Total } \\
\text { Heterogeneity }\end{array}$ & $\begin{array}{l}\text { 1994-1995 PR } \\
\text { 1994-1995 PR }\end{array}$ & $\begin{array}{l}212 \\
298 \\
510\end{array}$ & $\begin{array}{l}176 \\
224 \\
400\end{array}$ & $\begin{array}{r}36 \\
74 \\
110\end{array}$ & $\begin{array}{l}7.270 \\
0.004 \\
3.203 \\
4.071\end{array}$ & $\begin{array}{l}0.007 \\
0.950 \\
0.074 \\
\mathbf{0 . 0 4 4}\end{array}$ \\
\hline $\begin{array}{l}\text { JL } 24 \times\left(\text { ICGV } 86158 \times J L 24 F_{1}\right) \\
\text { Jl } 24 \times\left(\text { JL } 24 \times \text { ICGV } 86158 F_{1}\right) \\
\text { Total } \\
\text { Heterogeneity }\end{array}$ & $\begin{array}{l}\text { 1994-1995 PR } \\
\text { 1994-1995 PR }\end{array}$ & $\begin{array}{l}329 \\
188 \\
517\end{array}$ & $\begin{array}{l}239 \\
135 \\
\mathbf{3 7 4}\end{array}$ & $\begin{array}{r}90 \\
53 \\
143\end{array}$ & $\begin{array}{l}0.974 \\
1.021 \\
1.950 \\
0.045\end{array}$ & $\begin{array}{l}0.324 \\
0.312 \\
0.163 \\
\mathbf{0 . 8 3 2}\end{array}$ \\
\hline $\begin{array}{l}\text { ICGV } 87378 \times\left(\text { ICGV } 87378 \times J_{L} 24 F_{1}\right) \\
\text { ICGV } 87378 \times\left(\text { JL } 24 \times \text { ICGV } 87378 \text { F }_{1}\right) \\
\text { Total } \\
\text { Heterogeneity }\end{array}$ & $\begin{array}{l}\text { 1995-1996 PR } \\
1995-1996 \text { PR }\end{array}$ & $\begin{array}{r}24 \\
245 \\
269\end{array}$ & $\begin{array}{r}18 \\
187 \\
205\end{array}$ & $\begin{array}{r}6 \\
58 \\
64\end{array}$ & $\begin{array}{l}0.000 \\
0.229 \\
0.209 \\
0.020\end{array}$ & $\begin{array}{l}0.999 \\
0.632 \\
0.648 \\
0.888\end{array}$ \\
\hline $\begin{array}{l}\text { JL } 24 \times\left(\text { ICGV } 87378 \times J_{L} 24 F_{1}\right) \\
\text { J1 } 24 \times\left(J_{2 L} 24 \times I C G V 87378 F_{1}\right) \\
\text { Total } \\
\text { Heterogeneity }\end{array}$ & $\begin{array}{l}1995-1996 \text { PR } \\
1995-1996 \text { PR }\end{array}$ & $\begin{array}{l}196 \\
275 \\
471\end{array}$ & $\begin{array}{l}136 \\
189 \\
\mathbf{3 2 5}\end{array}$ & $\begin{array}{r}60 \\
86 \\
146\end{array}$ & $\begin{array}{l}3.293 \\
5.771 \\
9.036 \\
0.028\end{array}$ & $\begin{array}{l}0.069 \\
0.016 \\
0.003 \\
0.867\end{array}$ \\
\hline
\end{tabular}


locus. This is interesting because these two parents do not have any commonality in their origin. The gene for dormancy in ICGV 86158 might have come from Virginia TMV 10, whereas in ICGV 87378 it might have existed in the Spanish background.

The inheritance of fresh seed dormancy in Spanish parents as observed in the present study is simple. This is contrary to the observations of Stokes and Hull (1930) who found complex inheritance, and Hull (1937) and Nautiyal et al. (1994) who suggested polygenic-quantitative inheritance in different sets of genotypes. However, in these studies seeds were cured for varying duration before germination testing, and the crosses studied were between non-dormant Spanish or Valencia and dormant Virginia types. Seed curing reduces seed dormancy, and the degree of reduction depends on method of curing (Bear and Bailey, 1974). Further, intervarietal crosses between different subspecies give more complex ratios for various traits than those within the same subspecies of peanut (Coffelt and Hammons, 1972).

The monogenic nature of fresh seed dormancy in genotypes ICGV 86158 and ICGV 87378 makes them a preferred choice as sources of fresh seed dormancy in a Spanish-Valencia breeding program.

\section{REFERENCES}

Bailey, W.K., and R.O. Hammons. 1975. Registration of Chico peanut germplasm. Crop Sci. 15:105.

Bear, J.E., and W.K. Bailey. 1974. Effect of curing and storage environment on seed dormancy of several genotypes of Virginia-type peanuts, Arachis hypogaea L. Am. Peanut Res. Educ. Assoc. J. 5:15-19.
Coffelt, T.A., and R.O. Hammons. 1972. Inheritance of sterile brachytic in an intraspecific cross of Arachis hypogaea L. Crop Sci. 12:82-84.

Hammons, R.O. 1973. Genetics of Arachis hypogaea. p. 135-173. In C.T. Wilson (ed.) Peanut: Culture and uses. American Peanut Research and Education Assoc., Stillwater, OK.

Hull, F.H. 1937. Inheritance of rest period of seeds and certain other characters in the peanut. Fla. Agric. Exp. Sta. Tech. Bull. 314.

John, C.M., C.R. Seshadri, and R.M. Bhavanishankar. 1948. Dormancy in groundnut. Madras Agric. J. 25:1-9.

Ketring, D.L., and P.W. Morgan. 1971. Physiology of oilseeds. II. Dormancy release in Virginia-type peanut seeds by plant growth regulators. Plant Physiol. 47:488-492.

Ketring, D.L., and P.W. Morgan. 1972. Physiology of oilseeds. IV. Role of endogenous ethylene and inhibitory regulators during natural and induced afterripening of dormant Virginia-type peanut seeds. Plant Physiol. 50:382-387.

Khalfaoui, J.L.B. 1991. Inheritance of seed dormancy in a cross between two Spanish peanut cultivars. Peanut Sci. 18:65-67.

Lin, H., and C.Y. Lin. 1971. Studies on the seed dormancy of peanuts. III. inheritance of seed dormancy of peanuts. J. Agric. Res. (Taiwan) $20: 49-53$.

Miller, O.H., and E.E. Burns. 1971. Internal color of Spanish peanut hulls as an index of kernel maturity. J. Food Sci. 36:669-670.

Nautiyal, P.C., V. Ravindra, and A. Bandyopadhyay. 1994. Peanut seed dormancy. ACIAR- Food Legume Newsl. 21:2.

Patil, G.D., S.C. Desale, P.S. Patil, and S.S. Patil. 1980. 'Phule Pragati' A high yielding early bunch groundnut variety for Maharashtra. J. Maharastra Agric. Univ. 5:47-52.

Ramchandran, M., N.S. Lognathan, C.S. Sridharan, N.R. Chandrasekharan, and P. Krishnaswami. 1967. Evolution of dormant bunch groundnut strains by hybridization. Ind. J. Agric. Sci. 37:429-436.

Stokes, W.E., and F.H. Hull. 1930. Peanut breeding. J. Am. Soc. Agron. 22:1004-1019.

Upadhyaya, H.D., S.N. Nigam, M.J.V. Rao, A.G.S. Reddy, N. Yellaiah, and N.S. Reddy, 1997. Registration of five Spanish peanut germplasm with fresh seed dormancy. Crop Sci. 37:1027. 